
\title{
25 Research Square \\ The Effect of G-C3N4 on Bacterial Community in Sediment of Xiang River Under Tetracycline Pressure
}

\section{Xuemei Hu}

Central South University of Forestry and Technology

\section{Kuan Peng}

Central South University of Forestry and Technology

\section{Yijun Chen}

Central South University of Forestry and Technology

\section{Shuguang Liu}

National Engineering Laboratory for Applied Forest Ecological Technology in Southern China

\section{Yunlin Zhao}

Central South University of Forestry and Technology

\section{Xiaoyong Chen}

National Engineering Laboratory for Applied Forest Ecological Technology in Southern China

Yaohui Wu ( $\nabla$ wyh752100@163.com )

Central South University of Forestry and Technology https://orcid.org/0000-0002-2112-7540

\section{Zhenggang Xu}

Northwest A \& F University

\section{Research Article}

Keywords: Microbial community, g-C3N4, Tetracycline, Microbial ecology

Posted Date: May 19th, 2021

DOI: https://doi.org/10.21203/rs.3.rs-513362/v1

License: (1) (1) This work is licensed under a Creative Commons Attribution 4.0 International License. Read Full License 


\section{Abstract}

As photocatalysts applied more and more often to treat pollutants by photocatalytic reactions, they may enter the environment via water spreading. Although there are some investigations about their influence on different organisms, little is known about its impact on the ecological microenvironment. To understand how photocatalysts effect sediment ecological microenvironment in the process of pollution remediation, the impact of typical photocatalyst g- $\mathrm{C}_{3} \mathrm{~N}_{4}$ (Graphitic carbon nitride) on rivered sediment community polluted by typical antibiotic tetracycline (TC) was investigated. The sediment samples were exposed to different concentrations of TC, $\mathrm{g}-\mathrm{C}_{3} \mathrm{~N}_{4}$ or TC/g- $\mathrm{C}_{3} \mathrm{~N}_{4}$ (exposed to $60,120,180 \mathrm{mg} / \mathrm{L} \mathrm{TC}$, or 25 , $75,125 \mathrm{mg} / \mathrm{kg} \mathrm{g}-\mathrm{C}_{3} \mathrm{~N}_{4}$, or $25,75,125 \mathrm{mg} / \mathrm{kg} \mathrm{g}-\mathrm{C}_{3} \mathrm{~N}_{4}$ plus $60,120,180 \mathrm{mg} / \mathrm{L} \mathrm{TC}$, respectively), and sediment bacterial community were analyzed by Illumina sequencing. The results indicated that the dominant bacterial phyla in the samples were Acidobacteriota, Proteobacteria, Actinobacteriota, Chloroflexi. The diversity and richness of microorganisms in riverbed sediment were increased a little bit by g- $\mathrm{C}_{3} \mathrm{~N}_{4}$ with different concentrations, which reached the highest value when exposed to $75 \mathrm{mg} / \mathrm{kg} \mathrm{g}$ $\mathrm{C}_{3} \mathrm{~N}_{4} \cdot \mathrm{g}-\mathrm{C}_{3} \mathrm{~N}_{4}$ lightly increased the percentage of relative abundance of Cyanobacteria. The bacterial communities' structure of the samples treated with $T C, g-C_{3} N_{4}$ or $T C / g-C_{3} N_{4}$ were distinguishable. $g-C_{3} N_{4}$ alone had little effect on microbial structure, while $\mathrm{TC} / \mathrm{g}-\mathrm{C}_{3} \mathrm{~N}_{4}$ had medium influence and $\mathrm{TC}$ had great impact on it. Under TC stress, $\mathrm{g}-\mathrm{C}_{3} \mathrm{~N}_{4}$ slowed down the growth of Cyanobacteria to some extent and restored the changes of bacterial community structure caused by TC, and reduced the residual TC in water body, thus eliminating the side effects of TC. The result shown that $\mathrm{g}-\mathrm{C}_{3} \mathrm{~N}_{4}$ could significantly reduce the residue of TC in riverbed sediment, without affecting the microbial ecology in the environment.

\section{Introduction}

Antibiotics are extensively used for human therapy, animal farming and for agricultural purposes (Martinez, 2009). Currently, antibiotics have been found at diverse residual concentrations in riverbed sediment, aquaculture, groundwater and so on (Archundia et al. 2017; Batt et al. 2006; Liu et al. 2018). In China, large quantities of various antibiotics are widely produced and used. Tetracyline (TC) is one of the typical antibiotics in livestock practice due to its high pharmacological activity and solubility in water (Chopra et al. 2001), and it is widely used for human therapy, animal husbandry, and aquaculture, which is ranked second worldwide and first in China for production and usage (Chopra et al. 2001). Significant concerns have been raised over the presence TCs in aquatic environments (Ji et al. 2009). TC had significant negative effects on soil microbial community function and obviously effects Shannon's diversity, evenness of bacteria (Kong et al. 2006). It can influence the microorganisms in the environment, inducing the emergence of dominant microbial populations and changing microbial community structure. It had been documented that under exposure of TC, the activity of nitrifying bacteria was prevented and an important Nitrifier, Nitrospira, was inhibited (Du et al. 2018; Shu et al. 2015), and Bacteroidetes and Acidobacteria were increased, while Actinobacteria and Firmicutes decreased under antibiotics exposure (Uddin et al. 2019). TC also residues would significantly inhibit sediment $\mathrm{N}$ and $\mathrm{C}$ cycling rates and reduce the abundance of functional microbial groups (He et al. 2021). 
Since TC was poorly biodegradable and toxic for microorganisms (Yahiat et al. 2011), various techniques have been developed to removal it from water, such as physical adsorption (Hu et al. 2019; Wu et al. 2019b), biodegradation (Wei et al. 2019), chemical oxidation (Yang et al. 2019; Zhu et al. 2019a) and photocatalytic degradation (Ye et al. 2019; Zheng et al. 2019). Photocatalytic degradation was widely considered as potential method since it used light as energy and could mineralize TC. g- $\mathrm{C}_{3} \mathrm{~N}_{4}$ was a commonly used photocatalyst as it had some advantages, such as energy conservation, sufficiently efficient, stable, inexpensive and capable of harvesting light (Wang et al. 2009). g- $\mathrm{C}_{3} \mathrm{~N}_{4}$ was widely applied in wastewater treatment, due to its low cytotoxicity and photoactivity with visible light (Luo et al. 2017), inspiring researchers to use it for the remediation of TC pollution (Yan et al. 2020). Previous studies have shown that $\mathrm{g}-\mathrm{C}_{3} \mathrm{~N}_{4}$ displayed enhanced photocatalytic activity for TC degradation (Hong et al. 2016; Xue et al. 2015). Direct contact of $\mathrm{g}-\mathrm{C}_{3} \mathrm{~N}_{4}$ and bacterial cells was indispensable for the cell inactivation (Deng et al. 2017), and $\mathrm{h}^{+}$was demonstrated as the dominant reactive species which could make the bacteria cells inactivated ( $\mathrm{Li}$ et al. 2017). $\mathrm{g}-\mathrm{C}_{3} \mathrm{~N}_{4}$ not only exhibited striking bactericidal but also showed high efficiency in breaking down and preventing formation of new biofilms in vitro (Wang et al. 2017).

Sediment microorganisms played an important role in the benthic food web and the biogeochemical cycle of water ecosystems as they changed with environmental conditions and reflected the pollutant status of water sediment via variations in their abundance, diversity, and structure (Yang et al. 2013). However, although there were many studies about the impact of TC on microorganism, there was still little information regarding $\mathrm{g}-\mathrm{C}_{3} \mathrm{~N}_{4}$ application in sediment, especially for TC pollution control and the potential ecotoxicity.

In this study, in order to investigate the potential ecotoxicity of $\mathrm{g}-\mathrm{C}_{3} \mathrm{~N}_{4}$ in the application of pollution remediation, $\mathrm{TC}$ was used as a typical environmental pollutant to explore the effect of $\mathrm{g}-\mathrm{C}_{3} \mathrm{~N}_{4}$ on bacterial community structure in riverbed sediment while it photodegraded TC. The outcomes from this study may provide important information on the feasibility of applying $\mathrm{g}-\mathrm{C}_{3} \mathrm{~N}_{4}$ photocatalysis for control of organism pollution.

\section{Materials And Methods}

\subsection{Soil treatment}

The riverbed sediment sampling for this study was conducted on July 2, 2020, and it was collected from the Xiang River $\left(112^{\circ} 94^{\prime} 71^{\prime \prime} \mathrm{E}, 28^{\circ} 14^{\prime} 23^{\prime \prime} \mathrm{N}\right)$ in Changsha, Hunan, China. The soil was collected from a depth of $10-20 \mathrm{~cm}$ by five-point sampling method. After removing plant residues, the sediment sample kept in crushed dried ice boxes for transportation to the laboratory. The collected samples were homogenized and considered as fresh riverbed sediment (labelled as $\mathrm{H}$ ), and divided into two parts for 16S rRNA sequencing and experimental design, respectively. The background physicochemical properties of the homogenized sediment samples, including pH, Total nitrogen (TN), Total phosphorus (TP), Total 
potassium (TK), Soil organic matter (SOM), Ammonium nitrogen $\left(\mathrm{NH}_{4}{ }^{+} \mathrm{N}\right)$, Nitrate nitrogen $\left(\mathrm{NO}_{3}{ }^{-}-\mathrm{N}\right)$ and TC concentration, were detected as illustrated in Table S1. The concentration of TC was detected by high performance liquid chromatography (HPLC), and these results showed that the residues of TC in the riverbed of the middle Xiang River was low (Table S1).

\subsection{Target pollutant (TC) and photocatalyst $\left(\mathrm{g}-\mathrm{C}_{3} \mathrm{~N}_{4}\right)$}

TC $\left(\mathrm{C}_{22} \mathrm{H}_{24} \mathrm{~N}_{2} \mathrm{O}_{8} \cdot \mathrm{HCl}\right.$,USP grade) was purchased from Shanghai Aladdin Biochemical Technology (Shanghai, China). $\mathrm{g}-\mathrm{C}_{3} \mathrm{~N}_{4}$ was prepared by literature reports by direct polycondensation of melamine (Hou et al., 2020). After being loaded into a porcelain boat with a lid, and placed in a tube furnace, $5 \mathrm{~g}$ melamine was heated at $550{ }^{\circ} \mathrm{C}$ for $4 \mathrm{~h}$ under $\mathrm{N}_{2}$ condition (rate: $5{ }^{\circ} \mathrm{C} / \mathrm{min}$ ), and then cooled naturally to room temperature. The obtained $\mathrm{g}-\mathrm{C}_{3} \mathrm{~N}_{4}$ was ground thoroughly into powder and stored at room temperature for further use.

\subsection{Sediment exposure experiment}

$10000 \mathrm{mg} / \mathrm{L} \mathrm{TC}$ solution was prepared by dissolving $1 \mathrm{~g}$ of TC in $100 \mathrm{~mL}$ sterile water. $100 \mathrm{mg}$ of H were paced into $500 \mathrm{~mL}$ flasks with $100 \mathrm{~mL}$ water. $10000 \mathrm{mg} / \mathrm{L}$ TC solution and a certain amount of $\mathrm{g}-\mathrm{C}_{3} \mathrm{~N}_{4}$ powder were added into the flasks to achieve the final exposure concentration of TC $(60,120,180 \mathrm{mg} / \mathrm{L})$, and the target exposure doses of $\mathrm{g}-\mathrm{C}_{3} \mathrm{~N}_{4}(25,75,125 \mathrm{mg} / \mathrm{kg})$, and then stirred for $3 \mathrm{~min}$ for even mixture. The mixture containing $60,120,180 \mathrm{mg} / \mathrm{L} \mathrm{TC}$ was marked as $T_{L}, T_{M}, T_{H}$, and containing 25, 75, 125 $\mathrm{mg} / \mathrm{kg} \mathrm{g}-\mathrm{C}_{3} \mathrm{~N}_{4}$ was labelled as $\mathrm{P}_{\mathrm{L}}, \mathrm{P}_{\mathrm{M}}, \mathrm{P}_{\mathrm{H}}$, respectively. The sediment without $\mathrm{TC}$ or g- $\mathrm{C}_{3} \mathrm{~N}_{4}$ was utilized as the control. Each treatment was prepared for three replicated $\left(C K, T_{L}, T_{M}, T_{H}, P_{L}, P_{M}, P_{H}, T_{L} P_{L}, T_{L} P_{M}, T_{L} P_{H}\right.$, $\left.T_{M} P_{L}, T_{M} P_{M}, T_{M} P_{H}, T_{H} P_{L}, T_{H} P_{M}, T_{H} P_{H}\right)$. The treatments samples were kept static in a homeothermic incubator at $30{ }^{\circ} \mathrm{C} \pm 1{ }^{\circ} \mathrm{C}$ under 2000 lux illumination with a light dark period of 12:12 h. After 30 days, each set of treatment was respectively collected together and homogenized, $1-2 \mathrm{~g}$ of the homogenized sediment samples were stored at $-80{ }^{\circ} \mathrm{C}$ for the analysis of bacterial community structure and diversity.

\subsection{HPLC analysis for TC}

The extraction method of TC in riverbed sediments was described in detail in the supplementary material. After filtering through $0.22 \mu \mathrm{m}$ microporous membrane and centrifuging at $13000 \mathrm{r} \cdot \mathrm{min}^{-1}$ for $10 \mathrm{~min}, 20$ $\mu \mathrm{L}$ sediment precipitate was applied to detected TC concentration at $360 \mathrm{~nm}$ by high-performance liquid chromatography (HPLC). The HPLC system (Shimadzu corporation,Kyoto, Japan) was equipped with the Symmetry ${ }^{\circledR}$ C18 column (length $\times$ I.D.: $25 \mathrm{~cm} \times 4.6 \mathrm{~mm} ; 5 \mu \mathrm{m}$ particles, Shimadzu corporation $\square$ Kyoto, Japan). Chromatographic conditions were as follows: liquid A, mobile phase $0.1 \%$ TFA ddH2O, liquid B, $0.1 \%$ TFA ACN (acetonitrile). The flow rate was $1 \mathrm{ml} \cdot \mathrm{min}^{-1}$, the equilibrium solution was $10 \% \mathrm{~B}$ solution, and the gradient rose to $30 \% \mathrm{~B}$ solution within 20 minutes.

\subsection{DNA Extraction and Illumina MiSeq Sequencing}

The treatments samples and $\mathrm{H}$ were used for the extraction of Microbial community genomic DNA using FastDNA Spin Kit (Omega Bio-tek, Norcross, GA, U.S.) for Soil according to manufacturer's instructions. 
The DNA extract was checked on $1 \%$ agarose gel, and DNA concentration and purity were determined with NanoDrop 2000 UV-vis spectrophotometer (Thermo Scientific, Wilmington, USA). The hypervariable region V3-V4 of the bacterial 16S rRNA gene were amplified with primer pairs 338F (5'-

ACCTACGGGAGGCAGCAG-3') and 806R (5'-GGACTACHVGGGTWTAAT-3') by an ABI GeneAmp 9700 PCR thermocycler $(A B I, C A, U S A)$. In this study, the high-throughput sequencing of all samples was completed by Shanghai Majorbio Bio-pharm Technology Co., Ltd.

\subsection{Statistical analysis}

The Shannon index and the number of observed OTUs of the bacterial community were calculated using Mothur software (version v.1.30.1,http://www.mothur.org). Principal coordinate analyses (PCoA) were used to compare the beta diversity of the bacterial communities between samples based on the Bray Curtis distance matrix in the $\mathrm{R}$ software package using the ape and vegan libraries. Redundancy analysis (RDA) was performed using the function rda of package vegan in $\mathrm{R}$ to test the significance of the relationship between $\mathrm{TC}$ or $\mathrm{g}-\mathrm{C}_{3} \mathrm{~N}_{4}$ and microbial community dynamics. Linear discriminant analysis (LDA) together with effect size measurements analysis (LEfSe) (http://huttenhower.sph.harvard.edu) was considered to recognizing of the biomakers among groups.

\section{Results And Discussion}

\subsection{Diversity of bacteria communities in riverbed sediment}

In all studied 17 soil samples, 779,643 high-quality sequences were totally obtained from the V3-V4 region of $16 \mathrm{~S}$ rRNA gene sequences clustered in 7,214 bacterial OTUs. The rarefaction curve of bacteria in the samples showed that when the number of reads reached about 3000, the Shannon indexes of all samples tended to be flat (Fig. 1a), and the curves tended to be flat, indicating that our sequencing depth was sufficient and can truly reflect the bacterial community in the sediment sample.

Understanding biological diversity is very important as it associate the function and stability of ecosystems (Yu et al. 2020). The bacterial diversity of the riverbed sediment associated with untreated and treated sediments ( $\mathrm{TC}, \mathrm{g}-\mathrm{C}_{3} \mathrm{~N}_{4}$ and $\mathrm{TC} / \mathrm{g}-\mathrm{C}_{3} \mathrm{~N}_{4}$ ) analyzed to identify whether different treatments shaped the environmental microbiome (Fig. 1b). The treatment way had a little influence on the bacterial richness. The richness (Chao 1) of bacterial communities of $\mathrm{H}$ was 3901.70 lower than that of $\mathrm{CK}$ (4227.06), and lower than those of samples exposed to TC (4326.21-5068.42), g- $\mathrm{C}_{3} \mathrm{~N}_{4}$ (4563.894939.65) and TC/g- $\mathrm{C}_{3} \mathrm{~N}_{4}$ (4641.95-4962.17), respectively. However, the exposure of TC, $\mathrm{g}-\mathrm{C}_{3} \mathrm{~N}_{4}$ and $\mathrm{TC} / \mathrm{g}-\mathrm{C}_{3} \mathrm{~N}_{4}$ almost not changed the diversity (Shannon index) of bacterial communities. Meanwhile, the Shannon in the samples containing $\mathrm{TC} / \mathrm{g}-\mathrm{C}_{3} \mathrm{~N}_{4}$ remained comparatively stable in the range 6.81-6.92.

Based on Bray-Curtis distance, PCoA was applied to examine the beta diversity of the samples to study the differences of bacterial community structure among them (Fig. 1c). The first two axes (PCoA1 and PCoA2) explained $19.07 \%$ and $16.37 \%$ of the total variance in the sediment bacterial communities, 
respectively. A clear separation was observed among three sample groups exposed to $T C, g-C_{3} N_{4}$ and $\mathrm{TC} / \mathrm{g}-\mathrm{C}_{3} \mathrm{~N}_{4}$. The difference between $\mathrm{H}$ and the samples treated by $\mathrm{TC} / \mathrm{g}-\mathrm{C}_{3} \mathrm{~N}_{4}$ was littler than that between $\mathrm{H}$ and the sediments treated by $\mathrm{TC}$ alone, but larger than that between $\mathrm{H}$ and the samples handled with $\mathrm{g}$ $\mathrm{C}_{3} \mathrm{~N}_{4}$ alone. It might conclude that major changes in bacterial diversities across the samples were attributed to the difference treatments, $\mathrm{g}-\mathrm{C}_{3} \mathrm{~N}_{4}$ alone had little effect on microbial structure, while $\mathrm{TC} / \mathrm{g}$ $\mathrm{C}_{3} \mathrm{~N}_{4}$ had medium influence and TC had great impact on it.

Five-Way Venn diagrams were constructed to understand the unique and shared OTUs among different treatments in each riverbed sediment (Fig. 1d). There was a high specific OTUs number in each sample group and the shared OTUs $(1,898)$ accounted for $26.31 \%$ of the total OTUs $(7,214)$. The number of specific OTUs in TC/g- $\mathrm{C}_{3} \mathrm{~N}_{4}$ treatment group (713) was highest, followed g- $\mathrm{C}_{3} \mathrm{~N}_{4}$ treatment group (228) and TC treatment group (181), suggesting that the specific richness of bacterial communities in samples exposed to $\mathrm{TC} / \mathrm{g}-\mathrm{C}_{3} \mathrm{~N}_{4}$ was the higher than those exposed to $\mathrm{TC}$ and $\mathrm{g}-\mathrm{C}_{3} \mathrm{~N}_{4}$. These indicated that $\mathrm{TC} / \mathrm{g}$ $\mathrm{C}_{3} \mathrm{~N}_{4}$ might be capable of increasing the existence of unique species which precisely affected the bacterial communities in sediment, increasing the Chao 1 index as depicted in Fig. 1b.

The TC in soil posed a high risk for bacterial communities (Pan et al. 2016), according to other researchers studies, TC could be used as $\mathrm{C}$ sources by surviving bacteria, produce TC-resistant bacteria, increasing the bacterial diversity of soil (Grenni et al., 2018; Ma et al., 2020; Ullah et al. 2019). The TC in environment could significantly restrain the microbe in its resistance spectrum, thus the bacteria adapting to TC gradually replaced those not acclimated the environment with TC (Zhang et al. 2013). Photocatalyst could produce some active groups, for example $\cdot \mathrm{O}_{2}{ }^{-}$and $\cdot \mathrm{OH}$, which could act on microorganism and substances in environment, thus changed the diversity of bacteria. Hou et al. (2020) observed that $\mathrm{g}-\mathrm{C}_{3} \mathrm{~N}_{4}$ had good biocompatibility in the environment and had a positive effect on the sediment environment. Therefore, $\mathrm{g}-\mathrm{C}_{3} \mathrm{~N}_{4}$ could increase the richness of bacterial communities in the sediment, which was similar to the effect caused by other photocatalyst, such as $\mathrm{TiO}_{2}$ ( $\mathrm{Li}$ et al. 2020). Up to now, a large number of studies on $\mathrm{g}-\mathrm{C}_{3} \mathrm{~N}_{4}$ composite photocatalyst inactivation of pathogenic bacteria, such as Staphylococcus aureus, Salmonella typhimurium, Escherichia coli (Heo et al. 2019; Tang et al. 2019).

Once external substances were added into sediment, there would be some corresponding changes in the environment, in order to cope with the varieties, the genetic characteristics, physiological and biochemical processes of some soil microorganisms will be changed. Thereby, some microbe was inhibited in sediment, while others in the environment may be stimulate to growth, which enhanced the generation and evolution of the microbes that had adapted to the conditions, corresponding promoted the number of them, and increasing the microbial diversity. At the same time, nutrient composition of sediment was changed by adding external material to the sediment, the structure of the bacterial community would be changed accordingly, thus varying the beta diversity. However, the changes in diversity induced by $\mathrm{g}-\mathrm{C}_{3} \mathrm{~N}_{4}$ was basically stable and similar to those induced by other photocatalysts, including biochar (Wu et al. 
2019a), $\mathrm{TiO}_{2}$ (Li et al. 2020) implying that it had little influence on species diversity and might be safer for environment.

\subsection{Composition of bacterial communities determined by Illumina MiSeq}

According to the annotation and abundance of OTU, a relative abundance table for phyla was obtained (Table S2). The number of bacteria phyla hosted in $\mathrm{H}$ and $\mathrm{CK}$ was 36 and 40 , respectively. $\ln \mathrm{T}_{\mathrm{L}}, \mathrm{T}_{\mathrm{M}}, \mathrm{T}_{\mathrm{H}}$, there was $41,43,43$ bacterial phyla, respectively; In $\mathrm{P}_{\mathrm{L}}, \mathrm{P}_{\mathrm{M}}, \mathrm{P}_{\mathrm{H}}$, there was 45,43 and 44 bacterial phyla, respectively; And in $T_{L} P_{L}, T_{L} P_{M}, T_{L} P_{H}, T_{M} P_{L}, T_{M} P_{M}, T_{M} P_{H}, T_{H} P_{L}, T_{H} P_{M}, T_{H} P_{H}$ hosted 42, 44, 43, 42, 44, 43, 42, 44, 43 bacterial phyla, respectively. The number of bacteria phyla in different treatment groups was similar, and in the same treatment group, the number was basically unchanged, implying the composition of bacteria phyla might not be effected obviously in the experiments.

The distribution of bacteria phyla in sediments handled by different ways were demonstrated in Table S3. The dominant phyla in all samples were Acidobacteriota, Proteobacteria, Actinobacteriota, Chloroflexi, and their share was about $70 \%$. Uddin et al. (2021) found that the above four phyla were account for about $60 \%$ of soil bacteria by analyzing the effect of four different antibiotics on paddy soils. Though the influence of $\mathrm{g}-\mathrm{C}_{3} \mathrm{~N}_{4}$ on sediment had rarely examined till now, the four dominant phyla in our research were agree with their studies. According to other relevant reports, these four bacteria phyla accounted for a large proportion in water and soil (Chopra et al. 2001). and they were also the dominant phylum in sediment, although the abundance of each phyla was various in different sediment (Welz et al. 2018). Due to the high proportion of the advantage bacterium group in the sediment, they had an important effect on maintaining the stability of community structure in different treatments.

The effect of TC on bacterial community structure in sediment was illustrated in Fig. 2a and Table S3. Compared to $\mathrm{CK}$, the abundance of some microorganism were differ from the samples treated by TC, especially the dominant bacteria, such as Actinobacteriota, Acidobacteriota and Firmicutes, that is TC had a greater impact $(p<0.05)$ on them. However, between different concentrations of TC, the changes of relative bacteria abundance at phyla level was insignificant $(p>0.05)$ between different concentrations of TC. The average abundance of Actinobacteriota, Acidobacteriota and Firmicutes was significantly decreased in TC treatment $(p<0.001)$, and its abundance was $17.33 \%, 14.14 \%$ and $6.04 \%$, respectively, however, in $\mathrm{CK}$, the relative abundance was $25.05 \%, 16.07 \%$ and $8.68 \%$, respectively, so these three phyla were regarded to be susceptible to TC application. The results were consistent with other reports, Alexandrino et al. (2017) also found that Actinobacteriota and Firmicutes were sensitive to TC.

The influence of $\mathrm{g}-\mathrm{C}_{3} \mathrm{~N}_{4}$ on bacterial community structure in sediment was demonstrated in Fig. $2 \mathrm{~b}$ and Table S3. Compared with the $\mathrm{CK}$, the presence of $\mathrm{g}-\mathrm{C}_{3} \mathrm{~N}_{4}$ significantly inhibited $(\mathrm{p}<0.001)$ the growth of Firmicutes and Actinobacteriota in riverbed sediment. But the growth of Acidobacteriota (20.89\%) was significantly improved $(\mathrm{p}<0.001)$ by $\mathrm{g}-\mathrm{C}_{3} \mathrm{~N}_{4}$, and the average abundance was increased about $4.82 \%$ in comparison of $\mathrm{CK}$. In the $\mathrm{P}_{\mathrm{L}}$ treatment group, the biomass of Cyanobacteria $(0.88 \%)$ was significantly 
lower $(\mathrm{p}<0.001)$ than that of $\mathrm{CK}(3.50 \%)$, this was indicated that $\mathrm{g}-\mathrm{C}_{3} \mathrm{~N}_{4}$ might inhibited the growth of Cyanobacteria. Based on the above results, it could be concluded that Firmicutes, Actinobacteriota, Acidobacteriota and Cyanobacteria were susceptible to g- $\mathrm{C}_{3} \mathrm{~N}_{4}$ exposure. Cyanobacteria was photoautotrophic organisms in aquatic ecosystems and ubiquitous in riverbed sediment, as well as a typical microorganism in the identification and detection of environmental pollution (Teta et al., 2019). Acidobacteria had the potential to degrade polymeric carbonaceous complexes and actively participate in the cycling of organic matter, and it played an important role in maintaining the structural stability of microorganism in the environment (Kalam et al. 2020). Cyanobacteria proliferate in large quantities, which could affect the microbial structure in the environment (Chen et al. 2020). Our results showed that g- $\mathrm{C}_{3} \mathrm{~N}_{4}$ could promoted Acidobacteriota, inhibited Cyanobacteria, and was beneficial to environmental pollution remediation. However, The growth of Cyanobacteria was effected by g- $\mathrm{C}_{3} \mathrm{~N}_{4}$ concentration, its abundance of $\mathrm{P}_{\mathrm{H}}$ treatment $(6.34 \%)$ was higher than that of $\mathrm{P}_{\mathrm{L}}$ treatment $(0.88 \%)$, it might due to the automatically agglomerate of $\mathrm{g}-\mathrm{C}_{3} \mathrm{~N}_{4}$ at high concentration, inactivating its function.

The impact of $\mathrm{TC} / \mathrm{g}-\mathrm{C}_{3} \mathrm{~N}_{4}$ on bacterial community structure in sediment was illustrated in Fig. $2 \mathrm{c}$ and Table S3. Compared with Actinobacteriota (25.05\%) and Firmicutes (8.68\%) in the CK treatment group, the average abundance of Actinobacteriota (16.48\%) and Firmicutes (4.97\%) was significantly decreased $(\mathrm{p}<0.001)$ in $\mathrm{TC} / \mathrm{g}-\mathrm{C}_{3} \mathrm{~N}_{4}$ treatment. But, compared with the CK treatment groups $(16.07 \%)$, the average abundance of Acidobacteriota increased significantly $(\mathrm{p}<0.05)$ in $\mathrm{TC} / \mathrm{g}-\mathrm{C}_{3} \mathrm{~N}_{4}$ treatment groups $(20.71 \%)$. When the same does of $\mathrm{g}-\mathrm{C}_{3} \mathrm{~N}_{4}$ was added, the biomass of Cyanobacteria treated with low concentration of $\mathrm{TC}\left(\mathrm{T}_{\mathrm{L}} \mathrm{P}_{\mathrm{L}}=4.96 \%, \mathrm{~T}_{\mathrm{L}} \mathrm{P}_{\mathrm{M}}=4.14 \%, \mathrm{~T}_{\mathrm{L}} \mathrm{P}_{H}=3.81 \%\right)$ was higher than that treated with high concentration of $\mathrm{TC}\left(\mathrm{T}_{H} \mathrm{P}_{\mathrm{L}}=3.71 \%, \mathrm{~T}_{H} \mathrm{P}_{\mathrm{M}}=2.76 \%, \mathrm{~T}_{H} \mathrm{P}_{H}=2.16 \%\right)$. Meanwhile, the biomass of Chloroflexi $(11.79 \%-$ $13.73 \%$ ) and Gemmatimonadota $(3.23 \%-5.32 \%)$, which were the dominant microorganism in the sample, could be maintained in a stable range with the addition of both $\mathrm{TC}$ and $\mathrm{g}-\mathrm{C}_{3} \mathrm{~N}_{4}$, and the biomass of them were similar to that of $\mathrm{H}$ group, respectively. Acidobacteria was very important for the environment to keep the structural stability of microorganism as it potentially involved in the degradation of polymeric carbonaceous complexes and the cycling of organic matte (Kalam et al. 2020). Therefore, it was regarded as a kind of potential microorganism for environmental bioremediation and biotechnological applications (Kielak et al. 2017). Our study indicated that g- $\mathrm{C}_{3} \mathrm{~N}_{4}$ could significantly slow down the growth of Cyanobacteria and promote the growth of Acidobacteriota in the environment under TC pressure, thus it might beneficial for sediment to remediate TC pollution and haven't adverse effect on environment.

\subsection{Taxonomy-based comparisons of microbiota groups}

To identify the biomarkers in sediment samples, the microbial communities in different treatments was compared based on taxonomy, and the results were showed in (Fig. 3), in which LEfSe was applied to determine each group that was revealed in cladograms and histogram of LDA scores of 2.5 or more. The larger the score of LDA was, the more remarkable the difference caused by species abundance was. As depicted in the figure, there were obvious changes in dominant bacteria in sediment treated with TC, $\mathrm{g}$ - 
$\mathrm{C}_{3} \mathrm{~N}_{4}$ and $\mathrm{TC} / \mathrm{g}-\mathrm{C}_{3} \mathrm{~N}_{4}$ at the level of phylum, class, order, family and genus level. In the sediment treated with TC, more than 20 microbes including Actinobacteriota, Desulfuromonadia, Myxococcia were significantly enriched $(\mathrm{p}<0.05)$. Similarly, 8 groups of bacteria including Brocadiae, Entotheonellia, Dependentiae were obviously enriched $(p<0.05)$ in riverbed sediment treated with $\mathrm{g}-\mathrm{C}_{3} \mathrm{~N}_{4}$. However, in the sediment treated with $\mathrm{TC} / \mathrm{g}-\mathrm{C}_{3} \mathrm{~N}_{4}$, only 4 microbes were significantly enriched $(\mathrm{p}<0.05)$, such as Babeliae, Subgroup_25 and c_unclassified_p_Actinobacteriota. These indicated that the selected biomakers could clearly distinguish $(p<0.05)$ these three treatments and the difference caused by TC was the most, orderly followed by g- $\mathrm{C}_{3} \mathrm{~N}_{4}$ and $\mathrm{TC} / \mathrm{g}-\mathrm{C}_{3} \mathrm{~N}_{4}$. TC mainly affected the bacteria with high abundance, while g$\mathrm{C}_{3} \mathrm{~N}_{4}, \mathrm{TC} / \mathrm{g}-\mathrm{C}_{3} \mathrm{~N}_{4}$ mainly influenced the low abundance ones. The results suggested that $\mathrm{g}-\mathrm{C}_{3} \mathrm{~N}_{4}$ might mitigate the side effect caused by $\mathrm{TC}$ on sediment bacteria by reducing the difference of microbes in the environment.

\section{5 $\mathrm{TC}$ residue and Changes in species at genus level caused by $\mathrm{TC}$ and $\mathrm{g}-\mathrm{C}_{3} \mathrm{~N}_{4}$}

In order to study the effect of TC residue on bacteria community structure, we analyzed the TC concentration in sediment with different treatment, as well as the relative dominant bacterial genus (Fig. 4). As illustrated by Fig. 4a, there were no TC residues were detected out in $C K, P_{L}$ and $P_{H}$, suggesting that the original TC residue $(0.22 \mathrm{mg} / \mathrm{kg})$ came from $\mathrm{H}$ were degraded in these samples. In $T_{H}, T_{H} P_{L}$ and $\mathrm{T}_{\mathrm{H}} \mathrm{P}_{\mathrm{H}}$, the concentration of TC $\mathrm{s}$ was $22.68,14.42$ and $7.83 \mathrm{mg} / \mathrm{kg}$ respectively. Most of the TC added into the sediment samples were degraded by riverbed sediment, since there were only $22.68 \mathrm{mg} / \mathrm{kg}$ were existed in $T_{H}$ after 30 days. The TC concentration in $T_{H} P_{L}$ was $8.26 \mathrm{mg} / \mathrm{kg}$ lower than that in $T_{H}$, and higher than that in $\mathrm{T}_{\mathrm{H}} \mathrm{P}_{\mathrm{H}}$, indicating that in samples, $\mathrm{g}-\mathrm{C}_{3} \mathrm{~N}_{4}$ was also able to degrade $\mathrm{TC}$ and the degradation ability was improved by its concentration. $\mathrm{g}-\mathrm{C}_{3} \mathrm{~N}_{4}$ could effectively degrade TC in the water environment by some active groups, including $\cdot \mathrm{O}_{2}{ }^{-}$and $\cdot \mathrm{OH}$. (Guo et al. 2017; Zhu et al. 2019b). According reports, under the irradiation of visible light, the $\mathrm{g}-\mathrm{C}_{3} \mathrm{~N}_{4}$ could degrade about $40-90 \%$ TC in 30-120 min in water (Guo et al. 2019; Panneri et al. 2017), which was much higher than that in our experiment. This phenomenon might attribute to two facts: Firstly, the light intensity under our experimental condition was weak, so only a small number of photon were available for the degradation. Secondly, the composition of the sediment system was complex, which effected the light transmittance and further effected the photocatalytic activity of $\mathrm{g}-\mathrm{C}_{3} \mathrm{~N}_{4}$.

Figure $4 \mathrm{~b}$ and Table $\mathrm{S} 4$ demonstrated the dominant bacterial genus in different treated sediment. Compared with CK group, under the pressure of TC, the abundance of Bacillus (Firmicutes) decreased by $3.27 \%$, while the biomass of RB41 (Acidobacteriota) only increased by $0.57 \%$. The biomass of Bacillus (Firmicutes) in $\mathrm{P}_{\mathrm{L}}(2.21 \%)$ and $\mathrm{P}_{\mathrm{H}}(2.47 \%)$ was lower than that of $\mathrm{CK}(5.06 \%)$, however, the biomass of RB41 (Acidobacteriota) in $\mathrm{P}_{\mathrm{L}}(2.91 \%)$ and $\mathrm{P}_{\mathrm{H}}(2.00 \%)$ was higher than that of $\mathrm{CK}(0.89 \%)$. Compared with the $T_{H}$ group, the biomass of RB41 in $T_{H} P_{L}$ and $T_{H} P_{H}$ group was significantly increased $(p<0.001)$ to $3.22 \%$ and $2.77 \%$, respectively, and the abundance of Bacillus in $\mathrm{T}_{H} \mathrm{P}_{\mathrm{L}}$ and $\mathrm{T}_{H} \mathrm{P}_{H}$ group was increased. 
Under TC exposure, $g-\mathrm{C}_{3} \mathrm{~N}_{4}$ was beneficial to enrichment of norank_f_Vicinamibacteraceae and norank_f_Gemmatimonadaceae, belonging to the bacteria phyla of Acidobacteriota and Gemmatimonadota, respectively

Previous research had showed that RB41 was actively participated in the carbon cycle in sediment (Ito et al. 2019), RB41 was the dominant and sensitive microorganism in contaminated soil and played a positive role in environmental ecosystem (Ai et al. 2018; Shen et al. 2018). Based on the fact that its abundance increased in the treatment of $\mathrm{TC}$ and $\mathrm{g}-\mathrm{C}_{3} \mathrm{~N}_{4}$, it should be sensitive to them, and more to g$\mathrm{C}_{3} \mathrm{~N}_{4}$. Bacillus could fully degrade organic matter and eutrophic substances in sewage (Shen et al. 2020), at the same time, Bacillus was also a kind of beneficial bacteria that was beneficial to soil microecological stability. It could inhibit or kill pathogenic bacteria in the environment (Nicholson et al. 2002). It had been reported that antibiotics induced oxidative stress and inhibited the growth of Bacillus cells (Sannasimuthu et al. 2020). Based on the fact that compared to CK,the degree of decline in the content of Bacillus in $\mathrm{T}_{\mathrm{H}}$ was greater than that of samples contained $\mathrm{g}-\mathrm{C}_{3} \mathrm{~N}_{4}$, it was suggested that TC had obvious toxic effect on Bacillus, while $\mathrm{g}-\mathrm{C}_{3} \mathrm{~N}_{4}$ could reduce the toxic effect of TC on Bacillus. Hence, one inference was that the $\mathrm{g}-\mathrm{C}_{3} \mathrm{~N}_{4}$ might reduce the effect of TC on Bacillus in sediment.

In our experiment, we founded that the addition of $\mathrm{g}-\mathrm{C}_{3} \mathrm{~N}_{4}$ would reduce TC residue in sediment, and this trend was strengthened with the increase of the concentration of $\mathrm{g}-\mathrm{C}_{3} \mathrm{~N}_{4}$ (Fig. 4a). These results indicated that 1) $\mathrm{g}-\mathrm{C}_{3} \mathrm{~N}_{4}$ could degrade some organic substances, including $\mathrm{TC}$, and changed the nutrient composition of sediment, thus affecting the structure of microorganisms; 2) $\mathrm{g}-\mathrm{C}_{3} \mathrm{~N}_{4}$ could act on some microorganisms, change the growth of sensitive bacteria, thus affecting their ecological niche in the sediment. Based on the effect of $\mathrm{g}-\mathrm{C}_{3} \mathrm{~N}_{4}$ on dominant bacteria RB41 and Bacillus, it was indicated that g$\mathrm{C}_{3} \mathrm{~N}_{4}$ could improve the ability of sediment remediation and reduce the toxic effect of TC on beneficial bacteria, which was beneficial to the ecological health of sediment.

\subsection{Redundancy analysis (RDA) of bacterial community at the phylum level and class level}

The relationships between $\mathrm{TC}, \mathrm{g}-\mathrm{C}_{3} \mathrm{~N}_{4}$ and bacterial community was analyzed based on RDA score plot and depicted in Fig. 5. The impacts of each factor ( $\mathrm{TC}$ or $\mathrm{g}-\mathrm{C}_{3} \mathrm{~N}_{4}$ ) on bacterial community were represented by the length of arrows, and the cosine angle between arrows illustrated their relationship (smaller angle indicated more significant correlation). As shown in Fig. 5a, at the phylum level, axis 1 and 2 of the RDA plots explained up to $19.37 \%$ and $3.45 \%$, respectively. Specifically, TC positively affected ( $p$ <0.05) Chloroflexi, Proteobacteria, Myxococcota, Gemmatimonadetes, Actinobacteria and Firmicutes in riverbed sediment. Cyanobacteria had no significant correlation $(P<0.05)$ with TC. Previous research had shown that Firmicutes and Bacteroidetes were significantly positively correlated to total antibiotics, while Acidobacteria was significantly negatively correlated to them (Gao et al. 2020). Studies had indicated that Proteobacteria and Actinobacteria were dominated community of the TC resistant members (PalaOzkok et al. 2019), and Proteobacteria taken a great part in pollutant degradations and environmental 
remediation ( $\mathrm{Xu}$ et al. 2020). The concentration of $\mathrm{g}-\mathrm{C}_{3} \mathrm{~N}_{4}$ in riverbed sediment was negatively correlated $(\mathrm{P}<0.05)$ with Actinobacteria, Myxococcota, Firmicutes and Gemmatimonadetes and positively correlated $(\mathrm{p}<0.01)$ with Acidobacteriota, Proteobacteria, Cyanobacteria and Chloroflexi.

The RDA analysis for the relationship between $\mathrm{TC}$ or $\mathrm{g}-\mathrm{C}_{3} \mathrm{~N}_{4}$ and bacteria at genus level was illustrated in Fig. $5 b$, the first axis explained $17.73 \%$ of the total variance, whereas the second axis accounted for $4.48 \%$ of the total variance. It is noteworthy that TC has significant correlation $(p<0.05)$ with Gaiella, Nocardioides and Bacillus. Previous studies had also shown that Gaiella at genus level were significantly positively correlated to the total antibiotics (Gao et al. 2020). Nocardioides were crucial for bioremediation, notably, dehalogenation and denitration (Ito et al. 2019). However, g- $\mathrm{C}_{3} \mathrm{~N}_{4}$ exhibited negatively correlations $(\mathrm{p}<0.05)$ with Gaiella, Nocardioides and Bacillus. Gaiella was the sensitive genera that was negatively correlated to antibiotics perturbation (Uddin et al. 2019), g- $\mathrm{C}_{3} \mathrm{~N}_{4}$ had significant positive correlation $(\mathrm{p}<0.05)$ with RB41, which was positively correlated with soil carbon content and actively participated in the carbon cycle in soil environment (Ito et al. 2019). $\mathrm{g}-\mathrm{C}_{3} \mathrm{~N}_{4}$ had significant positive correlation $(p<0.05)$ with RB41, which was positively correlated with soil carbon content and actively participated in the carbon cycle in soil environment.

Using Spearman correlation analysis, the relationship between the top 30 bacterial genus and TC or g$\mathrm{C}_{3} \mathrm{~N}_{4}$ were examined to further investigated the influence of TC or $\mathrm{g}-\mathrm{C}_{3} \mathrm{~N}_{4}$ on bacteria community (Fig. 2s). According to the heatmap, TC and g- $\mathrm{C}_{3} \mathrm{~N}_{4}$ significantly correlated with the major phyla and genus. Acidobacteriota was the main phyla positively affected by $\mathrm{g}^{-} \mathrm{C}_{3} \mathrm{~N}_{4}(\mathrm{p}<0.01)$, Chloroflexi was the main phyla affected by TC $(p<0.05)$. RB41 $(p<0.05)$ and Ellin6067 $(p<0.001)$ were the main genus significantly associated with $\mathrm{g}-\mathrm{C}_{3} \mathrm{~N}_{4}$. These results were consistent with the results obtained with the RDA.

\section{Conclusion}

To our knowledge, this was the first-time research on the potential ecological toxicity of typical ptotocatalyst $\mathrm{g}-\mathrm{C}_{3} \mathrm{~N}_{4}$ by analyzing the change of sediment microbial community under TC exposures. The bacterial community and $\mathrm{TC}$ residue in the sediment under different conditions were examined. According to the results, compared with $\mathrm{CK}, \mathrm{TC}, \mathrm{g}-\mathrm{C}_{3} \mathrm{~N}_{4}$ and $\mathrm{TC} / \mathrm{g}-\mathrm{C}_{3} \mathrm{~N}_{4}$ treatments could increase microbial richness in the riverbed sediment, but kept microbial diversity basically stable. Beta diversity analysis showed that TC had greater influence on bacterial community structure, while g- $\mathrm{C}_{3} \mathrm{~N}_{4}$ and $\mathrm{TC} / \mathrm{g}-\mathrm{C}_{3} \mathrm{~N}_{4}$ had less influence on it. These indicated that $\mathrm{g}-\mathrm{C}_{3} \mathrm{~N}_{4}$ had less effect on species diversity and might be safer for environment. TC could inhibit the growth of Actinobacteriota, Acidobacteriota and Firmicutes in the riverbed sediment. $\mathrm{g}-\mathrm{C}_{3} \mathrm{~N}_{4}$ could significantly slow down the growth of Cyanobacteria and promote the growth of Acidobacteriota in the environment under TC exposure, thus it might beneficial for sediment to remediate TC pollution and reduce its adverse effect on environment. The LEfSe analysis showed that there were 20 classes, 8 classes and 4 classes of biomarkers in the sediments treated by TC, $g-C_{3} N_{4}$ and $\mathrm{TC} / \mathrm{g}-\mathrm{C}_{3} \mathrm{~N}_{4}$, respectively, $\mathrm{g}-\mathrm{C}_{3} \mathrm{~N}_{4}$ might mitigate the side effect caused by $\mathrm{TC}$ on sediment bacteria by 
reducing the difference of microbes in the environment. Meanwhile, in sediment g- $\mathrm{C}_{3} \mathrm{~N}_{4}$ could decrease TC residues and promoted the mass reproduction of RB41 as well as inhibited the toxic effect of TC on Bacillus. So, $\mathrm{g}-\mathrm{C}_{3} \mathrm{~N}_{4}$ would not adversely affect the ecological function of the revered sediment, and was an environmentally friendly photocatalyst. In conclusion, $\mathrm{g}-\mathrm{C}_{3} \mathrm{~N}_{4}$ might be expected to be used for TC pollution remediation in the environment.

\section{Declarations}

\section{Acknowledgments}

This work was supported in part by the Research Foundation of Education Bureau of Hunan Province (19A509), Key Projects of National Forestry and Grassland Bureau (201801) and Forestry Science and Technology Project of Hunan Province (XLK201920).

Funding: All the above funding has given the support.

\section{Data Availability}

Data are available by contacting Wu Yaohui (Wyh752100@163.com) and Hu Xuemei (1778897206@qq.com)

Consent to publish: All authors have approved the paper and agree with its publication.

\section{Author Contributions:}

Xuemei Hu: Conceptualization, Methodology, Data curation, Writing- Original raft.

Kuan Peng: Investigation, Methodology.

Yijun Chen: Methodology, data curation.

Shuguang Liu: Validation, Writing- Reviewing and Editing, Supervision.

Yunlin Zhao: Writing- Reviewing and Editing, Supervision.

Xiaoyong Chen: Writing- Reviewing and Editing, Supervision.

Yaohui Wu: Validation, Writing- Reviewing and Editing, Supervision.

Zhenggang Xu: Validation, Writing- Reviewing and Editing, Supervision.

\section{Compliance with ethical standards}

Conflict of interest: The authors declare no competing interests. 
Ethical approval: All the related authors confirmed there were no conflict of ethical approval.

Informed consent: Informed consent was obtained from all individual participants included in the study.

Publisher's note: Springer Nature remains neutral with regard to jurisdictional claims in published maps and institutional affiliations.

\section{References}

1. Ai C, Zhang S, Zhang X, Guo D, Zhou W, Huang S (2018) Distinct responses of soil bacterial and fungal communities to changes in fertilization regime and crop rotation. Geoderma 319:156-166

2. Alexandrino DAM, Mucha AP, Almeida CMR, Gao W, Jia Z, Carvalho MF (2017) Biodegradation of the veterinary antibiotics enrofloxacin and ceftiofur and associated microbial community dynamics. Science of The Total Environment. 581-582, 359-368

3. Archundia D, Duwig C, Lehembre F, Chiron S, Morel MC, Prado B et al (2017) Antibiotic pollution in the Katari subcatchment of the Titicaca Lake: Major transformation products and occurrence of resistance genes. Science of The Total Environment 576:671-682

4. Batt AL, Bruce IB, Aga DS (2006) Evaluating the vulnerability of surface waters to antibiotic contamination from varying wastewater treatment plant discharges. Environmental Pollution 142:295-302

5. Chen Y, Shen W, Wang B, Zhao X, Su L, Kong M et al (2020) Occurrence and fate of antibiotics, antimicrobial resistance determinants and potential human pathogens in a wastewater treatment plant and their effects on receiving waters in Nanjing, China. Ecotoxicology Environmental Safety 206:111371

6. Chopra I, Roberts M (2001) Tetracycline Antibiotics: Mode of Action, Applications, Molecular Biology, and Epidemiology of Bacterial Resistance. Microbiology Molecular Biology Reviews 65:232-260

7. Deng J, Liang J, Li M, Tong M (2017) Enhanced visible-light-driven photocatalytic bacteria disinfection by $\mathrm{g}-\mathrm{C}_{3} \mathrm{~N}_{4}-\mathrm{AgBr}$. Colloids Surfaces B: Biointerfaces 152:49-57

8. Du B, Wang R, Yang Q, Hu H, Li X, Duan X (2018) Impact of tetracycline on the performance and abundance of functional bacteria of a lab-scale anaerobic-aerobic wastewater treatment system. Biochemical Engineering Journal 138:98-105

9. Gao FZ, He LY, He LX, Zou HY, Zhang M, Wu DL et al (2020) Untreated swine wastes changed antibiotic resistance and microbial community in the soils and impacted abundances of antibiotic resistance genes in the vegetables. Science of The Total Environment 741:140482

10. Grenni P, Ancona V, Barra Caracciolo A (2018) Ecological effects of antibiotics on natural ecosystems: A review. Microchemical Journal 136:25-39

11. Guo F, Li M, Ren H, Huang X, Shu K, Shi W et al (2019) Facile bottom-up preparation of Cl-doped porous $\mathrm{g}-\mathrm{C}_{3} \mathrm{~N}_{4}$ nanosheets for enhanced photocatalytic degradation of tetracycline under visible light. Separation Purification Technology 228:115770 
12. Guo F, Shi W, Guan W, Huang H, Liu Y (2017) Carbon dots/g- $\mathrm{C}_{3} \mathrm{~N}_{4} / \mathrm{ZnO}$ nanocomposite as efficient visible-light driven photocatalyst for tetracycline total degradation. Separation Purification Technology 173:295-303

13. He G, Jiang X, Yao L, Liu G, Yang Y, Jiang Y et al (2021) Effects of tetracycline on nitrogen and carbon cycling rates and microbial abundance in sediments with and without biochar amendment. Chemosphere 270:129509

14. Heo NS, Shukla S, Oh SY, Bajpai VK, Lee SU, Cho HJ et al. ((2019) Shape-controlled assemblies of graphitic carbon nitride polymer for efficient sterilization therapies of water microbial contamination via 2D g- $\mathrm{C}_{3} \mathrm{~N}_{4}$ under visible light illumination. Materials Science Engineering: C 104:109846

15. Hong Y, Jiang Y, Li C, Fan W, Yan X, Yan M et al (2016) In-situ synthesis of direct solid-state Z-scheme $\mathrm{V}_{2} \mathrm{O}_{5} / \mathrm{g}-\mathrm{C}_{3} \mathrm{~N}_{4}$ heterojunctions with enhanced visible light efficiency in photocatalytic degradation of pollutants. Applied Catalysis B: Environmental 180:663-673

16. Hou F, Liu J, Zhang Y, Zhao C, Xiao X, Zou J et al (2020) Synthesis of metallic copper modified g$\mathrm{C}_{3} \mathrm{~N}_{4}$ by molecular self-assembly structure and its combined catalytic performance with activated sludge. Journal of Hazardous Materials 388:121754

17. Hu A, Zhang W, You Q, Men B, Liao G, Wang D (2019) A green and low-cost strategy to synthesis of tunable pore sizes porous organic polymers derived from waste-expanded polystyrene for highly efficient removal of organic contaminants. Chemical Engineering Journal 370:251-261

18. Ito K, Takagi K, Kataoka R, Kiyota H, Iwasaki A (2019) Dissipation, dehalogenation, and denitration of chloroaromatic compounds by Nocardioides sp. strain PD653: Characterization of the substrate specificity. Journal of Pesticide Science 44:171-176

19. Ji L, Chen W, Duan L, Zhu D (2009) Mechanisms for strong adsorption of tetracycline to carbon nanotubes: A comparative study using activated carbon and graphite as adsorbents. Environmental science technology 43:2322-2327

20. Kalam S, Basu A, Ahmad I, Sayyed RZ, El-Enshasy HA, Dailin DJ et al (2020) Recent Understanding of Soil Acidobacteria and Their Ecological Significance: A Critical Review. Frontiers in Microbiology. 11

21. Kielak AM, Castellane TC, Campanharo JC, Colnago LA (2017) Characterization of novel Acidobacteria exopolysaccharides with potential industrial and ecological applications. Scientific reports 7:378-382

22. Kong WD, Zhu YG, Fu BJ, Marschner P, He JZ (2006) The veterinary antibiotic oxytetracycline and Cu influence functional diversity of the soil microbial community. Environmental Pollution 143:129-137

23. Li K, Wu H, Wan L, Yang J, Rong J, Mu X et al (2020) Microbial community differences in constructed wetland substrates driven by $\mathrm{TiO}_{2}$-NPs. Chinese Journal of Ecology 39:4068-4077

24. Li J, Yin Y, Liu E, Ma Y, Wan J, Fan J et al (2017) In situ growing $\mathrm{Bi}_{2} \mathrm{MoO}_{6}$ on $\mathrm{g}-\mathrm{C}_{3} \mathrm{~N}_{4}$ nanosheets with enhanced photocatalytic hydrogen evolution and disinfection of bacteria under visible light irradiation. Journal of Hazardous Materials 321:183-192 
25. Liu X, Lu S, Guo W, Xi B, Wang W (2018) Antibiotics in the aquatic environments: A review of lakes, China. Science of The Total Environment 627:1195-1208

26. Luo B, Chen M, Zhang Z, Xu J, Li D, Xu D et al (2017) Highly efficient visible-light-driven photocatalytic degradation of tetracycline by a Z-scheme g- $\mathrm{C}_{3} \mathrm{~N}_{4} / \mathrm{Bi}_{3} \mathrm{TaO}_{7}$ nanocomposite photocatalyst. Dalton transactions (Cambridge, England: 2003). 46, 8431-8438

27. Ma J, Sheng GD, Chen QL, O'Connor P (2020) Do combined nanoscale polystyrene and tetracycline impact on the incidence of resistance genes and microbial community disturbance in Enchytraeus crypticus? Journal of Hazardous Materials 387:122012

28. Martinez JL (2009) Environmental pollution by antibiotics and by antibiotic resistance determinants. Environmental Pollution 157:2893-2902

29. Nicholson WL (2002) Roles of Bacillus endospores in the environment. Cellular Molecular Life Sciences 59:410-416

30. Pala-Ozkok I, Ubay-Cokgor E, Jonas D, Orhon D (2019) Kinetic and microbial response of activated sludge community to acute and chronic exposure to tetracycline. Journal of Hazardous Materials 367:418-426

31. Pan M, Chu LM (2016) Adsorption and degradation of five selected antibiotics in agricultural soil. Science of The Total Environment. 545-546, 48-56

32. Panneri S, Ganguly P, Mohan M, Nair BN, Mohamed AAP, Warrier KG et al (2017) Photo-regenerable, bifunctional granules of carbon doped $\mathrm{g}-\mathrm{C}_{3} \mathrm{~N}_{4}$ as adsorptive photocatalyst for the efficient removal of tetracycline antibiotic. Acs Sustainable Chemistry 5:1610-1618

33. Sannasimuthu A, Sharma D, Paray BA, Al-Sadoon MK, Arockiaraj J (2020) Intracellular oxidative damage due to antibiotics on gut bacteria reduced by glutathione oxidoreductase-derived antioxidant molecule GM15. Archives of Microbiology 202:1127-1133

34. Shen J, Liu Z, Yu H, Ye J, Long Y, Zhou P et al (2020) Systematic stress adaptation of Bacillus subtilis to tetracycline exposure. Ecotoxicology Environmental Safety 188:109910

35. Shu D, He Y, Yue H, Wang Q (2015) Microbial structures and community functions of anaerobic sludge in six full-scale wastewater treatment plants as revealed by 454 high-throughput pyrosequencing. Bioresource Technology 186:163-172

36. Tang C, Liu C, Han Y, Guo Q, Ouyang W, Feng H et al (2019) Nontoxic Carbon Quantum Dots/g- $\mathrm{C}_{3} \mathrm{~N}_{4}$ for Efficient Photocatalytic Inactivation of Staphylococcus aureus under Visible Light. Advanced Healthcare Materials 8:1801534

37. Teta R, Esposito G, Casazza M, Zappa CJ, Endreny TA, Mangoni A et al (2019) Bioindicators as a tool in environmental impact assessment: Cyanobacteria as a sentinel of pollution. International Journal of Sustainable Development Planning 14:1-8

38. Uddin M, Chen J, Qiao X, Tian R, Arafat Y, Yang X (2019) Bacterial community variations in paddy soils induced by application of veterinary antibiotics in plant-soil systems. Ecotoxicology Environmental Safety 167:44-53 
39. Ullah M, Dijkstra F (2019) Fungicide and Bactericide Effects on Carbon and Nitrogen Cycling in Soils: A Meta-Analysis. Soil Systems 3:23

40. Wang X, Maeda K, Thomas A, Takanabe K, Xin G, Carlsson M J et al (2009) A metal-free polymeric photocatalyst for hydrogen production from water under visible light. Nature Materials 8:271-275

41. Wang Z, Dong K, Liu Z, Zhang Y, Chen Z, Sun H et al (2017) Activation of biologically relevant levels of reactive oxygen species by $\mathrm{Au} / \mathrm{g}-\mathrm{C}_{3} \mathrm{~N}_{4}$ hybrid nanozyme for bacteria killing and wound disinfection. Biomaterials 113:145-157

42. Wei Z, Li W, Zhao D, Seo Y, Spinney R, Dionysiou DD et al (2019) Electrophilicity index as a critical indicator for the biodegradation of the pharmaceuticals in aerobic activated sludge processes. Water Research 160:10-17

43. Welz PJ, Khan N, Prins A (2018) The effect of biogenic and chemically manufactured silver nanoparticles on the benthic bacterial communities in river sediments. Science of The Total Environment 644:1380-1390

44. Wu B, Yang Q, Yao F, Chen S, He L, Hou K et al. ( (2019a) Evaluating the effect of biochar on mesophilic anaerobic digestion of waste activated sludge and microbial diversity. Bioresource Technology 294:122235

45. Wu M, Zhao S, Tang M, Jing R, Shao Y, Liu X et al (2019b) Adsorption of sulfamethoxazole and tetracycline on montmorillonite in single and binary systems. Colloids Surfaces A: Physicochemical Engineering Aspects 575:264-270

46. Xu J, Liu X, Lv Y, Guo X, Lu S (2020) Response of Cyperus involucratus to sulfamethoxazole and ofloxacin-contaminated environments: Growth physiology, transportation, and microbial community. Ecotoxicology Environmental Safety 206:111332

47. Xue J. Ma S, Zhou Y, Zhang Z, He M (2015) Facile Photochemical Synthesis of Au/Pt/g- $\mathrm{C}_{3} \mathrm{~N}_{4}$ with Plasmon-Enhanced Photocatalytic Activity for Antibiotic Degradation. ACS Applied Materials Interfaces 7:9630-9637

48. Yahiat S, Fourcade F, Brosillon S, Amrane A (2011) Removal of antibiotics by an integrated process coupling photocatalysis and biological treatment-Case of tetracycline and tylosin. International Biodeterioration Biodegradation 65:997-1003

49. Yan Y, Zhou X, Yu P, Li Z, Zheng T (2020) Characteristics, mechanisms and bacteria behavior of photocatalysis with a solid Z-scheme $\mathrm{Ag} / \mathrm{AgBr} / \mathrm{g}-\mathrm{C}_{3} \mathrm{~N}_{4}$ nanosheet in water disinfection. Applied Catalysis A: General. 590, 117282

50. Yang J, Liang Y, Li K, Yang G, Yin S (2019) One-step low-temperature synthesis of $\mathrm{OD} \mathrm{CeO}_{2}$ quantum dots/2D BiOX $(\mathrm{X}=\mathrm{Cl}, \mathrm{Br})$ nanoplates heterojunctions for highly boosting photo-oxidation and reduction ability. Applied Catalysis B: Environmental. 250, 17-30

51. Yang X, Huang S, Wu Q, Zhang R, Liu G (2013) Diversity and vertical distributions of sediment bacteria in an urban river contaminated by nutrients and heavy metals. Frontiers of Environmental Science Engineering 7:851-859 
52. Ye S, Yan M, Tan X, Liang J, Zeng G, Wu H et al (2019) Facile assembled biochar-based nanocomposite with improved graphitization for efficient photocatalytic activity driven by visible light. Applied Catalysis B: Environmental 250:78-88

53. Yu P, Sun Y, Huang Z, Zhu F, Sun Y, Jiang L (2020) The effects of ectomycorrhizal fungi on heavy metals' transport in Pinus massoniana and bacteria community in rhizosphere soil in mine tailing area. Journal of Hazardous Materials 381:121203

54. Zhang W, Huang MH, Qi FF, Sun PZ, Van Ginkel SW (2013) Effect of trace tetracycline concentrations on the structure of a microbial community and the development of tetracycline resistance genes in sequencing batch reactors. Bioresource Technology 150:9-14

55. Zheng J, Zhang L (2019) Designing 3D magnetic peony flower-like cobalt oxides $/ g-\mathrm{C}_{3} \mathrm{~N}_{4}$ dual Zscheme photocatalyst for remarkably enhanced sunlight driven photocatalytic redox activity. Chemical Engineering Journal 369:947-956

56. Zhu G, Yu X, Xie F, Feng W (2019a) Ultraviolet light assisted heterogeneous Fenton degradation of tetracycline based on polyhedral $\mathrm{Fe}_{3} \mathrm{O}_{4}$ nanoparticles with exposed high-energy $\{110\}$ facets. Applied Surface Science 485:496-505

57. Zhu Q, Sun Y, Na F, Wei J, Xu S, Li Y et al (2019b) Fabrication of CdS/titanium-oxo-cluster nanocomposites based on a Ti32 framework with enhanced photocatalytic activity for tetracycline hydrochloride degradation under visible light. Applied Catalysis B: Environmental 254:541-550

\section{Figures}


a

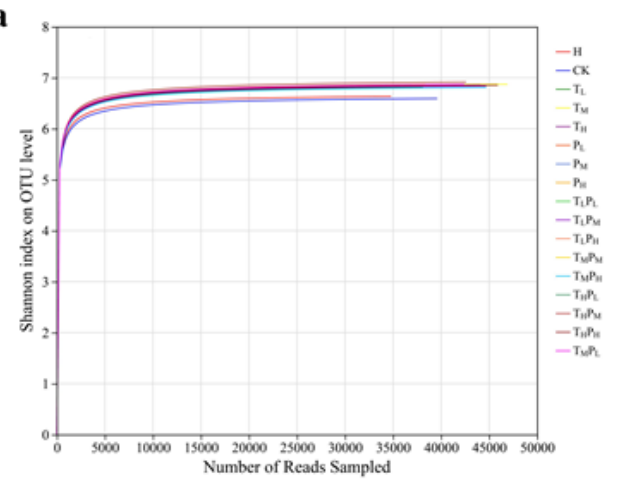

b
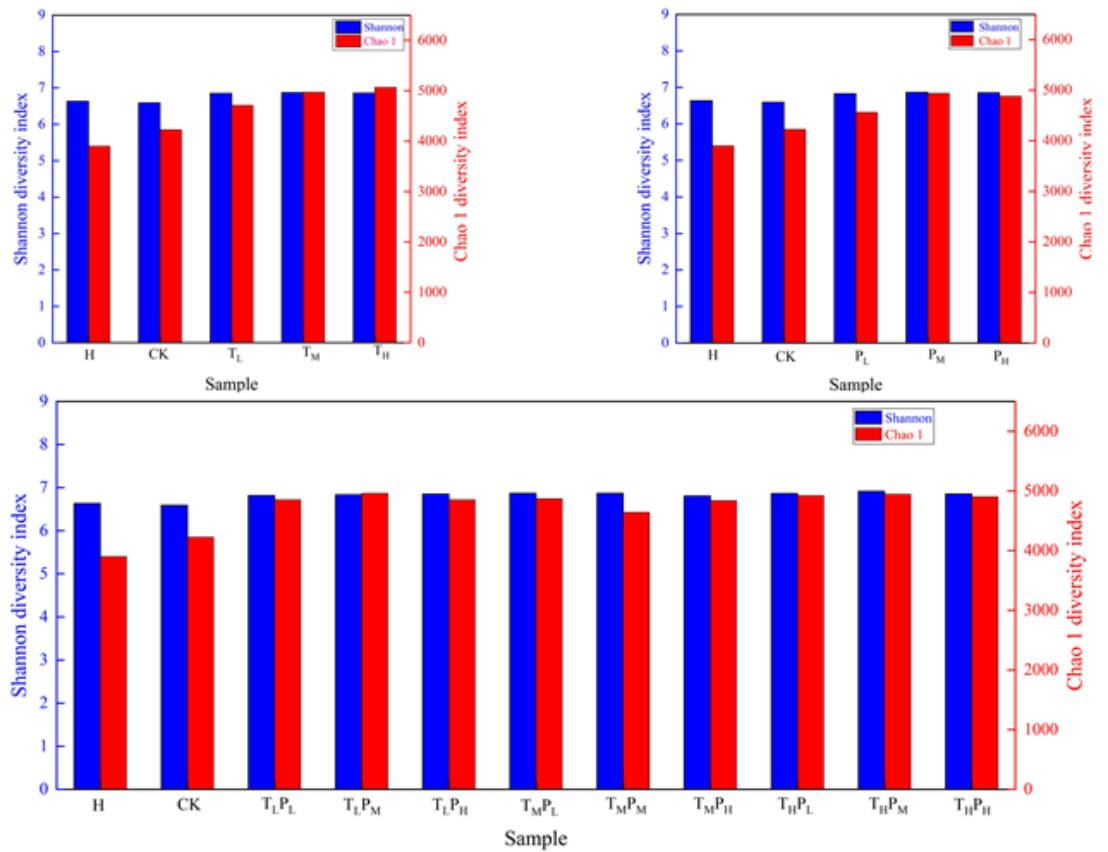

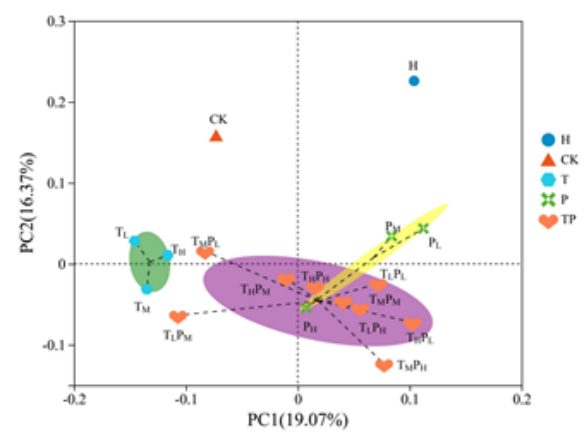

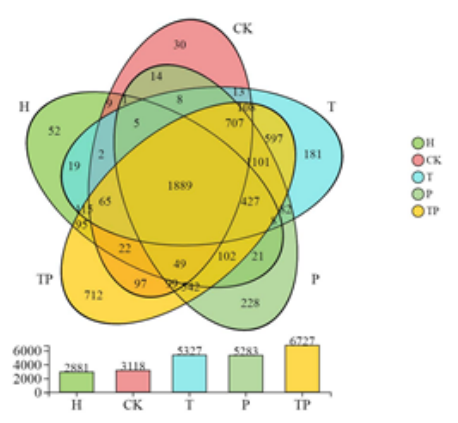

Figure 1

Diversity and richness of the bacteria communities (a) Bacteria relative abundance of OTUs identified in the 17 soil samples, $\mathrm{H}, \mathrm{CK}$ refer to 0 day of sediment, 30 days of sediment, respectively; TL, TM, TH refer to the system contain $60,120,180 \mathrm{mg} / \mathrm{L} \mathrm{TC}$, respectively; PL, PM, PH refer to the system contain 25,75 , $125 \mathrm{mg} / \mathrm{kg}$ g-C3N4, respectively. (b) Shannon diversity index and Chao 1 of bacteria, (c) Bacterial communities structure analysis by principal coordinates (PCoA), (d) Taxonomic diversity of bacterial 
communities, venn diagrams showed the shared and specific OTUs of bacterial, H, CK, T, P and TP, refer to 0 day of sediment, 30 days of sediment, sediment treated with different concentrations of TC at 30 days, sediment treated with different concentrations of g-C3N4 at 30 days and sediment treated with different amounts of TC/g-C3N4 at 30 days, respectively.

a

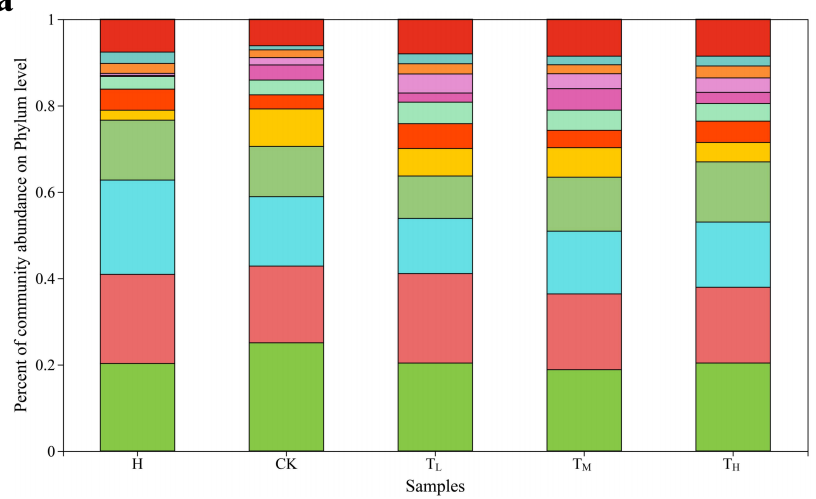

b

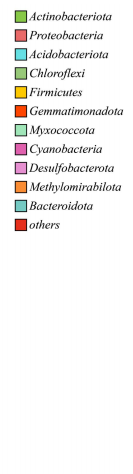

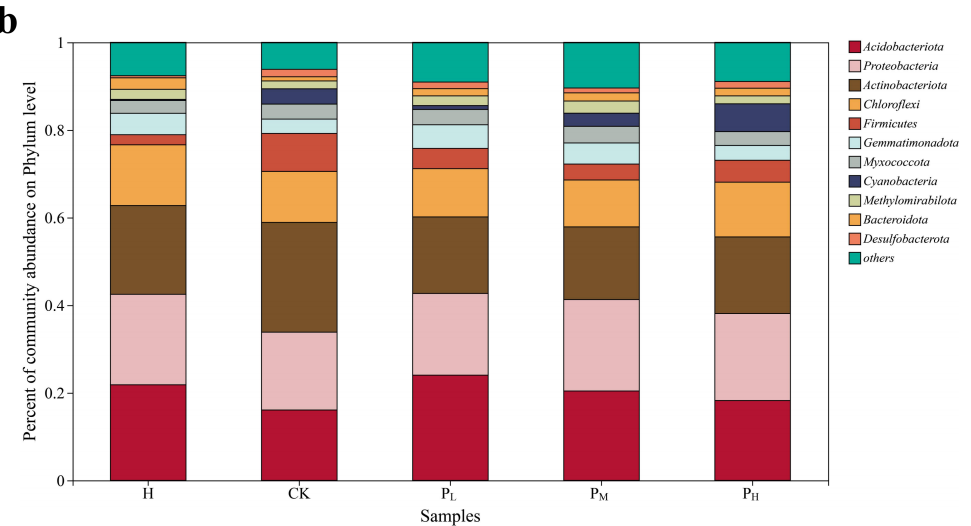

c

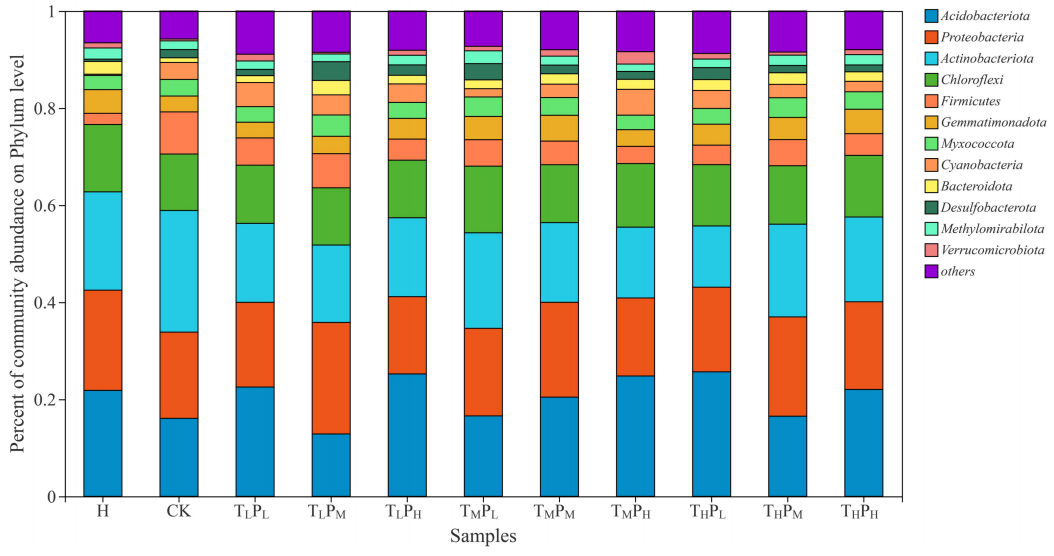

Figure 2

Bacterial communities structure analysis by principal coordinates at the phyla level, only top (relative bacterial abundance $>1.5 \%$ ) bacterial taxa are shown. (a) Microbial community structure of sediment exposed to g-C3N4 at 30 days, (b) Microbial community structure of sediment exposed to TC at 30 days, (c) Microbial community structure of sediment treated with different amounts of TC/g-C3N4 at 30 days. $\mathrm{TL}, \mathrm{TM}, \mathrm{TH}$ refer to the system contain $60,120,180 \mathrm{mg} / \mathrm{L} \mathrm{TC}, \mathrm{PL}, \mathrm{PM}, \mathrm{PH}$ refer to the system contain 25 , $75,125 \mathrm{mg} / \mathrm{kg}$ g-C3N4, respectively. 
$\mathbf{a}$

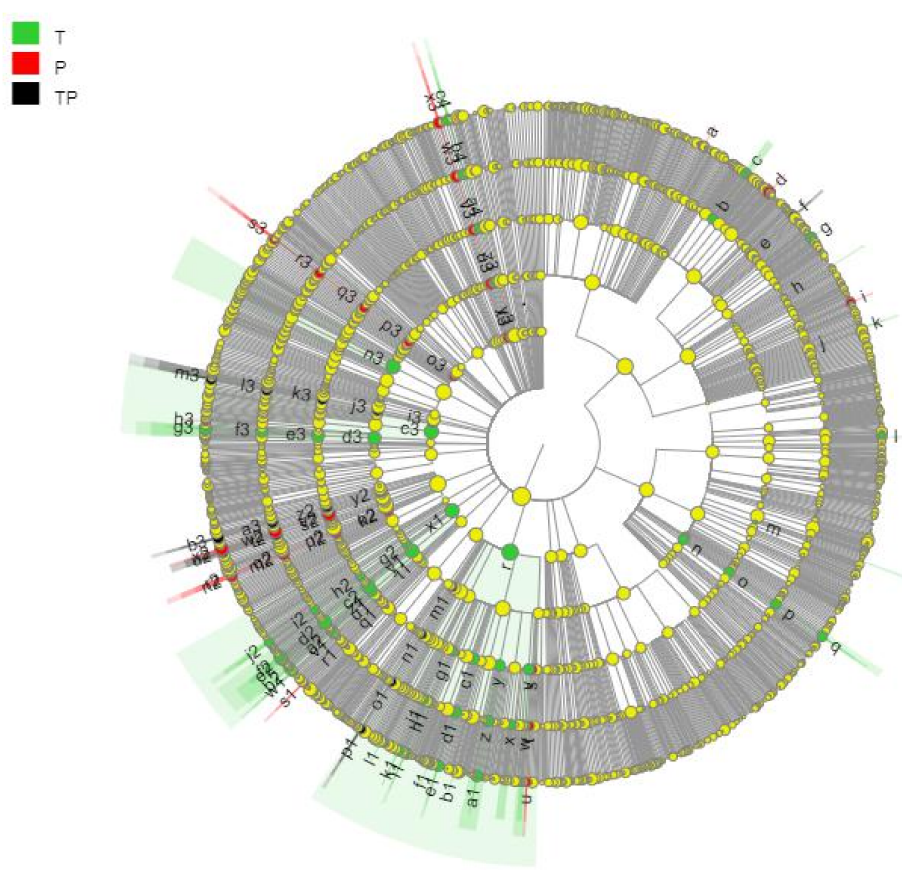

b

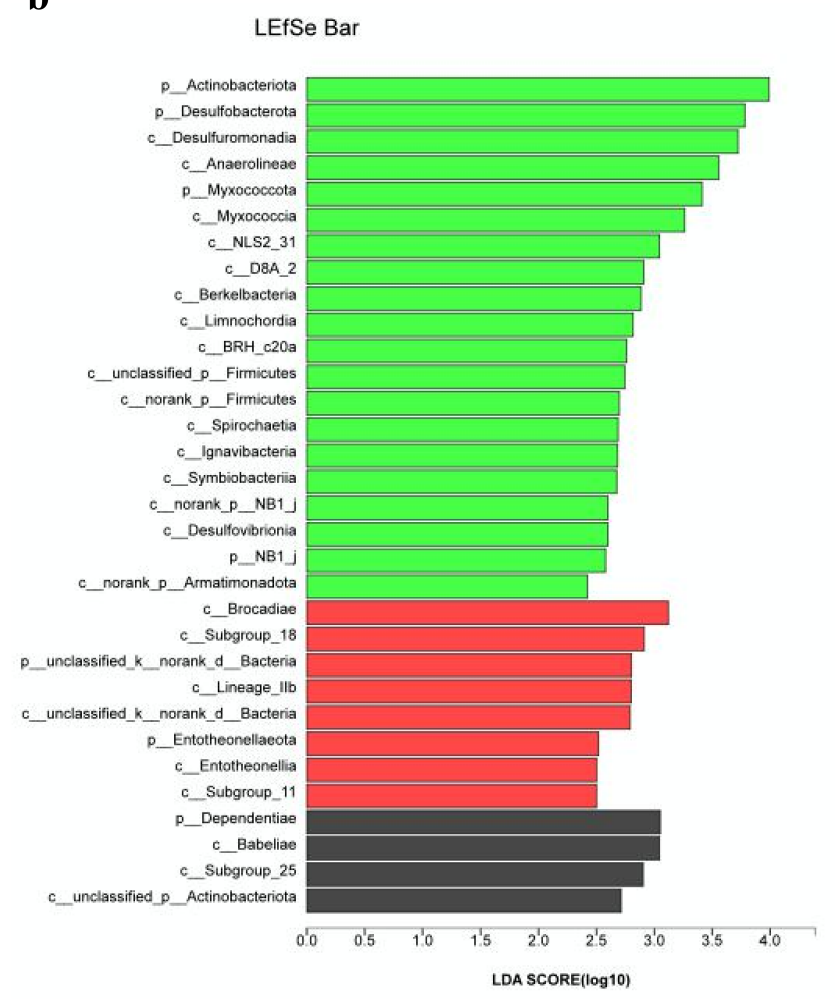

\section{Figure 3}

Structures of soil microbiota (a) Cladogram demonstrate the relationships among microbiota taxonomic units from the bacteria level of phylum down to the level of genus, the color of green $(T)$, red $(P)$, and black (TP) refers to sediment treated with different concentrations of TC at 30 days, sediment treated with different concentrations of g-C3N4 at 30 days and sediment treated with different amounts of TC/gC3N4 at 30 days, respectively. (b) Histogram of LDA scores of taxonomic units, The taxa with the absolute LDA scores $>2.5$.

a

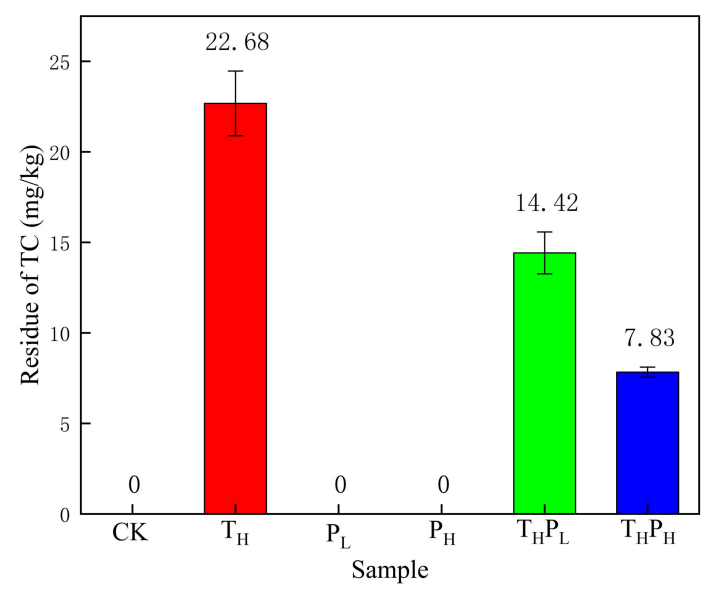

b

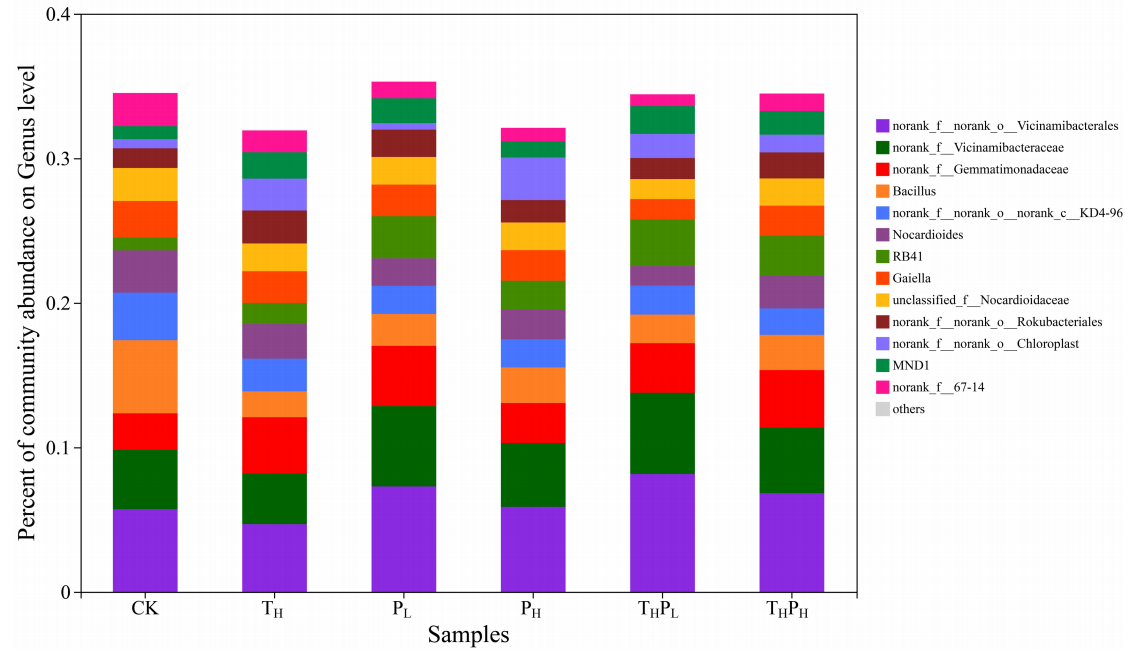

Figure 4 
Changes of community structure during the treatment of TC with g-C3N4. (a) The residual condition of TC in samples with different treatments. CK refer to the 30 days of sediment; $\mathrm{TH}$ refer to the sediment system contain $180 \mathrm{mg} / \mathrm{L} \mathrm{TC}$; PL, PH refer to the sediment system contain $25,125 \mathrm{mg} / \mathrm{kg}$ g-C3N4, respectively. (b) Community abundance percentage of typical samples at genus leve.

a

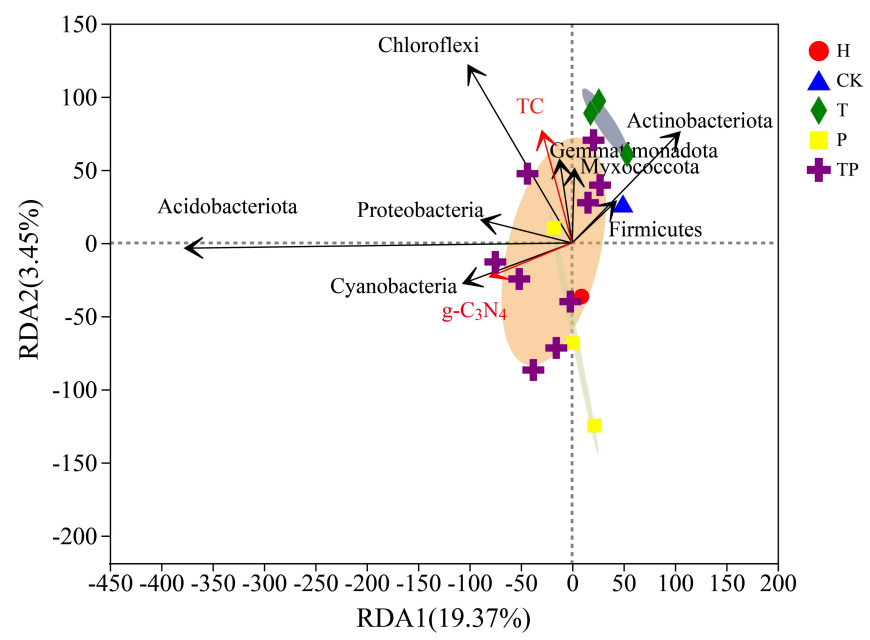

b

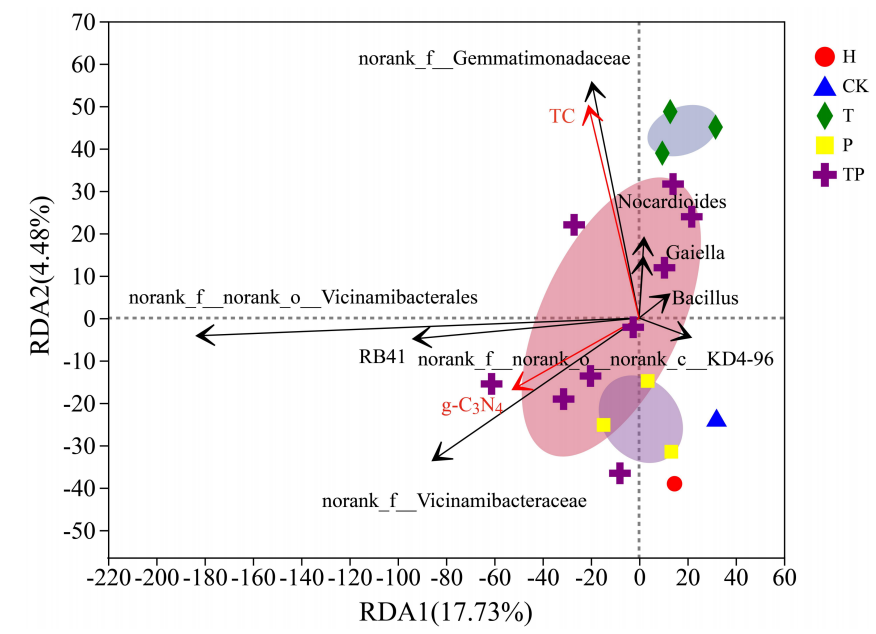

\section{Figure 5}

Redundant analysis (RDA) of TC and g-C3N4 with different concentrations in sediment and bacterial community structure in sediment. Arrows indicate the direction and magnitude of environmental factors associated with bacterial community structure. (a) RDA of eight highest relative abundance of bacteria at phylum level. (b) RDA of eight highest relative abundance of bacteria at genus level. H, CK, T, P and TP, refer to 0 day of sediment, 30 days of sediment, sediment treated with different concentrations of TC at 30 days, sediment treated with different concentrations of g-C3N4 at 30 days and sediment treated with different amounts of TC/g-C3N4 at 30 days, respectively.

\section{Supplementary Files}

This is a list of supplementary files associated with this preprint. Click to download.

- SupplementaryMaterial.pdf 